\title{
Influence of Foaming Agents on the Properties of Foamed Concretes Having Various Densities
}

\author{
Kim, Jin-Man Jeong, Ji-Yong* \\ Department of Architectural Engineering, KongJu National University, SeoBuk-Gu, Cheonan, 303-717, Korea
}

\begin{abstract}
Four types of foaming agents, including Alcohol Ethoxy Sulfate (AES), Alpha Olefin Sulfonate (AOS), Vegetable Soap (VS), and Fe-Protein (FP), are widely used in the construction field. These have different surface tensions and viscosities in water of the same concentration, affecting the flow speed of liquid, size and distribution of foam, and foam stability. However, there is a lack of data regarding the properties of foam concrete using various foam agents. The purpose of this study is to investigate influence of foaming agents on the properties of foamed concretes with various densities. We find that the foaming agent type has little effect on the density, compressive strength, and thermal conductivity of foam concrete, but considerably affects the unit weight of foam, flow and flexural strength of foamed concrete. While almost all properties of foam concrete are affected by density in fresh or hardened state, the potential energy changed by slurry density and the viscosity of foam are dominant factors in the flowability of foam slurry.
\end{abstract}

Keywords : foamed concrete, foaming agent, surface tension, compressive strength, thermal conductivity

\section{Introduction}

As the number of high-rise buildings has been on the rise, the risk of fire in buildings has been a major social concern. In particular, incidents in which upward flame spreads rapidly through external and internal passages have been reported frequently. To address this problem, research on improvements to building material has been actively carried out. Of the various building materials, organic insulation material is light and has very low thermal conductivity, but has the shortcomings of being vulnerable to fire and creating hazardous gas fumes when it burns. On the other hand, while

Received : July 25, 2011

Revision received : December 30, 2011

Accepted : January 2, 2012

* Corresponding author : Jeong, Ji-Yong

[Tel: 82-41-521-9338, E-mail: jjynogada@kongju.ac.kr]

(c)2012 The Korea Institute of Building Construction, All rights reserved. inorganic insulation material is heavy and has high heat conductivity[1], it is non-combustible and very stable[1], and does not generate hazardous gas fumes. Many researchers are now striving to maximize the advantages of organic and inorganic insulation material, while addressing their various disadvantages.

Autoclaved lightweight concrete (ALC) is a representative example of an inorganic insulation material. ALC is a lightweight concrete that is chemically formed by adding aluminum powder, whose pore sizes tend to appear more irregular and larger in diameter. Although it is categorized as a foamed concrete, as is ALC, when the prefoaming method is used, it is called foamed concrete. By adjusting the volume of foam bubbles, the target strength can be obtained more easily, and thus it is used in the construction and civil works, especially ondol (heated floor) plastering and slope stability. Nevertheless, few studies have been conducted on its 
properties in relation to the manufacturing method, material used and curing, and slurry state and hardened state.

Foamed concrete is affected by the foaming agent, powder material and curing method. The foaming agent is an admixture that promotes the formation of more foam bubbles by lowering the surface tension using surfactants, which are molecules having both hydrophilic and oleophilic segments. A foaming agent can be categorized by its base material, which has different surface tension and viscosity. Surface tension and viscosity are the main triggers to change the foam structure and its properties, and they become very important elements in manufacturing foamed concrete. As a foaming agent has different surface activity, the surface tension of the medium in which it is dissolved becomes different[2]. The long chain structure of a surfactant molecules leads to higher viscosity. The type of surfactant that is used can cause the chain structure and viscosity to be changed, accordingly[3]. These properties have an impact on the foam stability in the process from the slurry to hardened state, as well as on the foaming rate, structure, size and distribution[4].

In addition, the properties of foamed concrete vary depending on the volume of foam used[5]. If a small volume of foam in the foamed concrete, foam coalescence does not occur. However, when increase the amount of foam, the smaller the distance between the foam bubbles, the more foam coalescence takes place. Foam coalescence has a great impact on the size and distribution of foam[6].

However, few studies have been done on the effect on surface tension, viscosity and the volume of foam of a surfactant, and for this reason the workers in charge of quality control on construction sites still depend on their own experience rather than on scientific knowledge. For this reason, this research aims to provide reference data on the appropriate amount of a surfactant for foamed concrete based on a review of the properties of foamed concrete according to which of the four different types of surfactant are used in construction and civil work in Korea.

\section{Research plan and method}

\subsection{Research plan}

Table 1 indicates the research plan. As surfactants that have a negative ion group and are widely used for the foamed concrete in construction and civil works, AES (Alcohol Ethoxy Sulfate), AOS (Alpha Olefin Sulfonate, VS (Vegetable Soap) and FP (Feprotein) were used for experiments. The volume for foam stability was increased by $150 \mathrm{l} / \mathrm{m}^{3}$ each time from the volume (100-700) $\ell / \mathrm{m}^{3}$.

Table 2 shows the proportions of foamed concrete. As shown in Table 2, the water/binder ratio was set at $40 \%$, the concentration of surfactant at $3 \%$, and $\mathrm{CaO} / \mathrm{SiO}_{2}$ mol ratio at 1.0 , taking into account autoclave curing $\left(180^{\circ} \mathrm{C}\right.$ at $\left.10 \mathrm{~atm}\right)$.

Table 1. Plan of experiment

\begin{tabular}{|c|c|c|}
\hline Factors & Levels & Testing items \\
\hline $\begin{array}{l}\text { Type of } \\
\text { foaming } \\
\text { agents }\end{array}$ & $\begin{array}{c}A E S^{1)}, A^{3(2)} \\
V^{3 !}, \mathrm{FP}^{4)}\end{array}$ & $\begin{array}{c}\text { Unit weight of foam } \\
\text { Flow } \\
\text { Slurry density } \\
\text { Oven dry density }\end{array}$ \\
\hline $\begin{array}{l}\text { Unit volume } \\
\text { of foam } \\
\left(\ell / \mathrm{m}^{3}\right)\end{array}$ & $\begin{array}{c}100,250 \\
400,550 \\
700\end{array}$ & $\begin{array}{l}\text { Compressive strength } \\
\text { Flexural strength } \\
\text { Thermal conductivity }\end{array}$ \\
\hline
\end{tabular}

1) AES : Alcohol Ethoxy Sulfate

2) AOS : Alpha Olefin Sulfonate

3) VS: Vegetable Soap

4) $\mathrm{FP}: \mathrm{Fe}-$ Protein

\subsection{Experimental method}

Figure 1 illustrates the process of foam bubble formation. For the foam bubble formation, surfactant was infused in water, and then the water went through a tube filled with beads. 
Table 2. Mix proportions of foamed concrete

\begin{tabular}{|c|c|c|c|c|c|c|c|c|c|}
\hline \multirow{2}{*}{$\begin{array}{l}\text { W/B } \\
(\%)\end{array}$} & \multirow{2}{*}{$\mathrm{C} / \mathrm{S}$} & \multirow{2}{*}{$\begin{array}{c}\text { Foaming } \\
\text { agent }\end{array}$} & \multirow{2}{*}{$\begin{array}{l}\text { Water } \\
\left(\mathrm{kg} / \mathrm{m}^{3}\right)\end{array}$} & \multirow{2}{*}{$\begin{array}{l}\text { Foam } \\
\left(\ell / m^{3}\right)\end{array}$} & \multicolumn{5}{|c|}{ Unit weight $\left(\mathrm{kg} / \mathrm{m}^{3}\right)$} \\
\hline & & & & & $P C^{1)}$ & $Q^{2)}$ & $A C^{3)}$ & $\mathrm{CH}^{4)}$ & $\mathrm{AG}^{5)}$ \\
\hline \multirow{5}{*}{40} & \multirow{5}{*}{1.0} & $\mathrm{AES}^{6)}$, & 160 & 700 & 189 & 168 & 19 & 9 & 15 \\
\hline & & $\mathrm{AOS}^{7}$ & 240 & 550 & 283 & 252 & 28 & 14 & 23 \\
\hline & & $V S^{8)}$ & 320 & 400 & 378 & 336 & 38 & 18 & 30 \\
\hline & & & 40 & 250 & 473 & 421 & 47 & 23 & 38 \\
\hline & & $\mathrm{FP}^{9 /}$ & 480 & 100 & 567 & 505 & 57 & 27 & 45 \\
\hline
\end{tabular}
1) PC:Portland Cement
2) Q:Quartz
3 AC:Alumina Cement
4) $\mathrm{CH}$ :Calcium Hydroxide
5) AG:Anhydride Gypsum
6) AES : Alcohol Ethoxy Sulfate
7) AOS : Alpha Olefin Sulfonate
8) VS : Vegetable Soap
9) $\mathrm{FP}: \mathrm{Fe}-$ Protein

The concentration of the water was set at $3 \%$. Foamed concrete was formed by adding foam bubbles to the paste created by mixing water, binder and superplasticizer for 3 minutes. In terms of oven dry density and compressive strength, the specimens were molded in a cubic mould $(100 \times 100 \times 100) \mathrm{mm}$, while in terms of heat conductivity and flexural strength the species were molded in a prism mould $(300 \times 300 \times 50) \mathrm{mm}$ and $(100 \times 100 \times 400) \mathrm{mm}$, respectively.

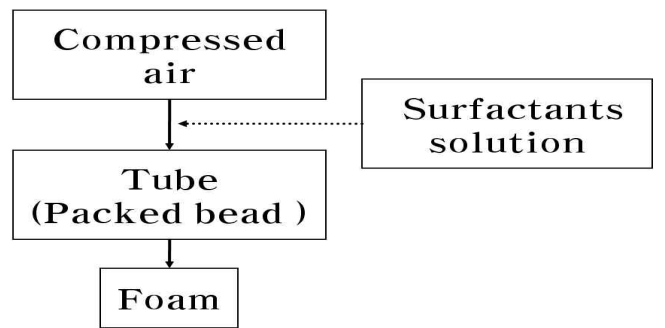

Figure 1. Schematic diagram of foam production method

Figure 2 illustrates the curing method, which consists of three steps: presteaming, steam and autoclave curing. First, presteaming was performed for 5 hours at $20 \pm 2{ }^{\circ} \mathrm{C}$ to minimize the loss of foam added in the paste. Second, steam curing was performed to develop the strength that could prevent the concrete separated from the mould to the drying autoclave machine from being damaged. To perform steam curing, the temperature was increased at a rate of $15^{\circ} \mathrm{C} /$ hour for 4 hours, and then kept at $80^{\circ} \mathrm{C}$ for 5 hours. Lastly, autoclave curing was implemented to develop the ultimate strength by making $\mathrm{SiO}_{2}$ and $\mathrm{CaO}$ react with each other, which is required to generate Tobermorite. The temperature was raised at a rate of $40^{\circ} \mathrm{C} /$ hour for 4 hours, and then kept at $180^{\circ} \mathrm{C}-10$ atm for 5 hours.

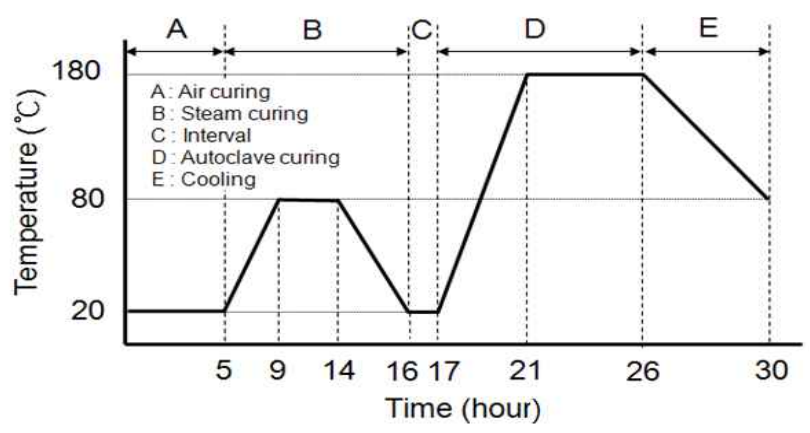

Figure 2. Curing process

The unit weight and slurry density were measured using a $3 \ell$-container. The flow of fresh concrete was measured in compliance with KS F 4039 foamed concrete for cast-in-site, and the slurry density was measured after a 3-minute stirring of foam bubbles with the cement paste. The oven dry density and compressive strength of the hardened cement were measured in compliance with KS F 2701 autoclaved lightweight aerated concrete block and ASTM C 49599a, standard test method for compressive strength of lightweight insulting concrete, respectively. The heat conductivity was measured using a heat flow meter in compliance with KS M 3808 cellular polystyrene (PS) for thermal insulation.

\subsection{Materials}

The synthetic surfactants were AES with sodium fatty and AOS with sulfur trioxide, while natural surfactants were alkali metal salt solution of carboxylic acid extracted from VS and FP. The properties of the surfactants are shown in Table. 3.

Ordinary Portland cement that meets the KS L 5201 was used, and alumina cement was added to prevent an antifoaming of bubbles that form the pore 
structure from occurring, as well as slaked lime to facilitate hydration, and anhydrous gypsum to prevent the cement from being rapidly set at an early stage. Table 4 shows the chemical properties of the materials, and naphthalene superplasticizer was used.

Table 3. Properties of surfactants

\begin{tabular}{lccc}
\hline Type & $\begin{array}{c}\text { Active } \\
\text { Matter }\end{array}$ & Relative Viscosity ${ }^{*}(\%)$ & $\begin{array}{c}\text { Surface } \\
\text { tension }(\mathrm{mN} / \mathrm{m})\end{array}$ \\
\hline $\mathrm{AES}^{11}$ & 28.2 & 17.21 & 47.2 \\
$\mathrm{AOS}^{2)}$ & 35.3 & 13.93 & 28.9 \\
VS $^{3)}$ & 25.7 & 16.39 & 44.5 \\
$\mathrm{FP}^{4)}$ & 35.8 & 9.02 & 66.1 \\
\hline 1) AES : Alcohol Ethoxy Sulfate & \\
2) AOS : Alpha Olefin Sulfonate & \\
3) VS : Vegetable Soap & \\
4) FP : Fe-Protein & \\
* : Solution concentration - 3\%(by weight) &
\end{tabular}

Table 4. Chemical properties of using binders

\begin{tabular}{ccccccc}
\hline Type & $\mathrm{CaO}$ & $\mathrm{SiO}_{2}$ & $\mathrm{Al}_{2} \mathrm{O}_{3}$ & $\mathrm{MnO}$ & $\mathrm{Fe}_{2} \mathrm{O}_{3}$ & $\mathrm{SiO}_{3}$ \\
\hline $\mathrm{PC}^{\prime \prime}$ & 72.06 & 11.16 & 2.24 & 0.10 & 5.49 & 5.22 \\
$\mathrm{AC}^{2)}$ & 37.13 & 2.78 & 59.79 & 0.04 & 0.22 & - \\
$\mathrm{Q}^{3)}$ & 1.23 & 88.09 & 5.02 & 0.08 & 3.45 & - \\
$\mathrm{CH}^{4)}$ & 93.82 & 1.37 & 0.59 & 0.09 & 1.44 & 1.53 \\
$\mathrm{AG}^{5)}$ & 38.01 & 2.28 & 0.82 & - & 0.16 & 58.61 \\
\hline
\end{tabular}

1) PC:Portland Cement

2) Q:Quartz

3) AC:Alumina Cement

4) $\mathrm{CH}$ :Calcium Hydroxide

5) AG:Anhydride Gypsum

\section{Experimental results}

The experimental results of foamed concrete according to foaming agent type and the volume of foam bubbles are shown in Table 5 .

\subsection{Unit weight of foam}

If surfactant lowers the surface tension and then air is infused (e.g. through stirring), foam is generated. The surface tension of water is usually (72 73) $\mathrm{mN} / \mathrm{m}$ at room temperature, but the surface tension of the water in which a surfactant is dissolved lowers to $(40 \sim 50) \mathrm{mN} / \mathrm{m}$, and thus it is easy for foam to be formed. Moreover, when the surfactant is used, the long chain of molecules of the surfactant causes flow and drainage of the liquid within the lamella to slow down, and thus the viscosity of the liquid increases[3]. For this reason, the shape of foam can be maintained for a long time without being broken.

Figure 3 indicates the unit weight of foam and the relative viscosity of the solution by foaming agent.

Table 5. Results of experiment

\begin{tabular}{|c|c|c|c|c|c|c|c|c|}
\hline $\begin{array}{c}\text { Type of foaming } \\
\text { agents }\end{array}$ & $\begin{array}{l}\text { Unit volume of } \\
\text { foam } \\
\left(\ell / \mathrm{m}^{3}\right)\end{array}$ & $\begin{array}{c}\text { Unit weight of } \\
\text { foam } \\
\left(\mathrm{kg} / \mathrm{m}^{3}\right)\end{array}$ & $\begin{array}{c}\text { Flow } \\
(\mathrm{mm})\end{array}$ & $\begin{array}{l}\text { Slurry density } \\
\qquad\left(\mathrm{t} / \mathrm{m}^{3}\right)\end{array}$ & $\begin{array}{l}\text { Oven dry density } \\
\qquad\left(\mathrm{t} / \mathrm{m}^{3}\right)\end{array}$ & $\begin{array}{l}\text { Compressive } \\
\text { strength } \\
(\mathrm{MPa})\end{array}$ & $\begin{array}{l}\text { Flexural strength } \\
\qquad(\mathrm{MPa})\end{array}$ & $\begin{array}{c}\text { Thermal } \\
\text { conductivity } \\
(\mathrm{W} / \mathrm{mK})\end{array}$ \\
\hline \multirow{5}{*}{$A E S^{1)}$} & 100 & \multirow{5}{*}{36.0} & 253 & 1.70 & 1.50 & 24.2 & 5.1 & 0.421 \\
\hline & 250 & & 259 & 1.42 & 1.25 & 17.9 & 3.7 & 0.377 \\
\hline & 400 & & 241 & 1.14 & 1.02 & 10.0 & 3.0 & 0.271 \\
\hline & 550 & & 219 & 0.82 & 0.71 & 4.0 & 1.3 & 0.214 \\
\hline & 700 & & 194 & 0.52 & 0.44 & 1.4 & 0.4 & 0.120 \\
\hline \multirow{5}{*}{$\mathrm{AOS}^{2)}$} & 100 & \multirow{5}{*}{41.0} & 268 & 1.70 & 1.52 & 27.7 & 7.7 & 0.466 \\
\hline & 250 & & 267 & 1.39 & 1.23 & 15.3 & 4.1 & 0.341 \\
\hline & 400 & & 251 & 1.11 & 0.96 & 8.9 & 2.8 & 0.252 \\
\hline & 550 & & 239 & 0.82 & 0.72 & 4.3 & 1.2 & 0.170 \\
\hline & 700 & & 190 & 0.49 & 0.35 & 0.7 & 0.3 & 0.101 \\
\hline \multirow{5}{*}{$V^{3}{ }^{3)}$} & 100 & \multirow{5}{*}{33.6} & 284 & 1.70 & 1.51 & 27.6 & 7.4 & 0.479 \\
\hline & 250 & & 250 & 1.47 & 1.30 & 18.2 & 5.9 & 0.395 \\
\hline & 400 & & 236 & 1.18 & 1.04 & 11.7 & 3.1 & 0.288 \\
\hline & 550 & & 216 & 0.83 & 0.74 & 4.5 & 1.7 & 0.194 \\
\hline & 700 & & 178 & 0.50 & 0.40 & 1.7 & 0.7 & 0.113 \\
\hline \multirow{5}{*}{$\mathrm{FP}^{4)}$} & 100 & \multirow{5}{*}{48.0} & 252 & 1.67 & 1.48 & 29.2 & 9.6 & 0.420 \\
\hline & 250 & & 248 & 1.40 & 1.23 & 18.7 & 6.3 & 0.355 \\
\hline & 400 & & 221 & 1.10 & 0.96 & 11.3 & 3.6 & 0.269 \\
\hline & 550 & & 181 & 0.79 & 0.66 & 4.9 & 1.6 & 0.194 \\
\hline & 700 & & 158 & 0.51 & 0.40 & 1.5 & 1.2 & 0.109 \\
\hline
\end{tabular}

1) AES : Alcohol Ethoxy Sulfate

2) AOS : Alpha Olefin Sulfonate

3) VS: Vegetable Soap

4) FP : Fe-Protein 
Unit weight by foaming agent was shown to be 48.0 $\left.\left.\left.\mathrm{kg} / \mathrm{m}^{3}(\mathrm{FP})\right\rangle 41.0 \mathrm{~kg} / \mathrm{m}^{3}(\mathrm{AOS})\right\rangle 36.0 \mathrm{~kg} / \mathrm{m}^{3}(\mathrm{AES})\right\rangle 33.6 \mathrm{~kg} /$ $\mathrm{m}^{3}(\mathrm{VS})$. The higher the unit weight is, the less likely it is that foam is formed, which is believed to be due to the fact that the lamella becomes thick in order to support the internal and external pressure. This property is in inverse proportion to the relative viscosity of liquid. The viscosity of solution is an essential element to keep the foam in shape. The higher the viscosity, the more foam bubbles can be formed with a lower amount of solution.

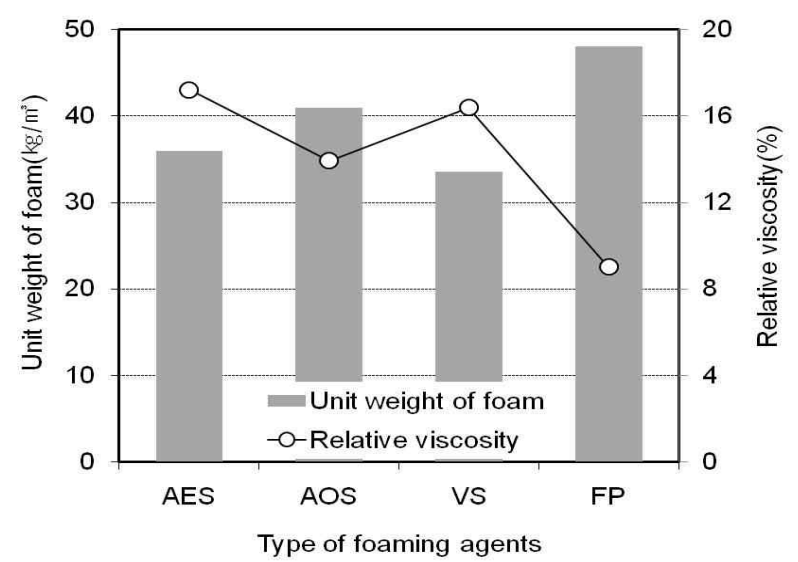

Figure 3. Unit weight of foam and relative viscosity according to type of foaming agents(AES : Alcohol Ethoxy Sulfate, AOS : Alpha Olefin Sulfonate, VS : Vegetable Soap, FP : Fe-Protein)

\subsection{Flow}

Figure 4 shows the flow according to type of foaming agent and unit volume of foam. At a given volume of foam, AOS, AES, VS and FP, in that order, were shown to be high overall, notwithstanding some exceptions. The higher the volume was, the lower the flow became. The flow according to type of foaming agent was shown to be similar with the property of surface tension. It is believed that the surface tension became lower due to the effective surfactants, and accordingly, the cohesion of foamed concrete was affected, changing the flow.

The flow was decreased according to the volume of foam since the density was lower, and accordingly, the flow energy became relatively smaller, and then the fluidity and drainage speed were also slower due to the long chain of molecules, and thus the viscosity of the liquid became higher.

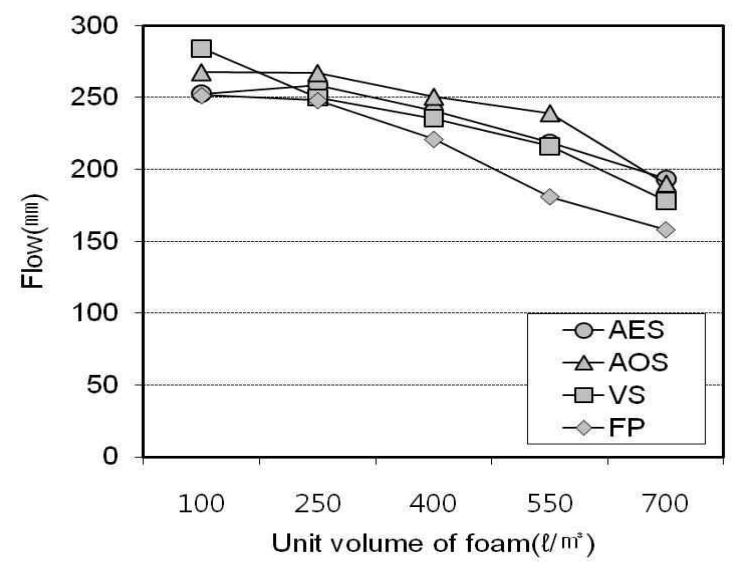

Figure 4. Flow according to type of foaming agents and unit volume of foam(AES : Alcohol Ethoxy Sulfate, AOS : Alpha Olefin Sulfonate, VS : Vegetable Soap, FP : Fe-Protein)

\subsection{Density}

Figures 5 and 6 illustrate slurry density and oven dry density according to type of foaming agents. The slurry density and oven dry density were shown to be similar regardless of the type of foaming agent, and there was $0.3 \mathrm{t} / \mathrm{m}^{3}$ of difference found in density according to the increase of $150 \ell / \mathrm{m}^{3} \mathrm{in}$ the foam volume.

Surface tension and viscosity of solution differ according to the type of foaming agent. These properties affect the lamella and interface of foam bubbles[7], and thus the sizes of foam bubbles are shown to be different[4]. The flow of liquid on the lamella and interface of foam bubbles is the main element that has an impact on the foam stability[6], which may affect the breaking of foam in the process of mixing material or curing. However, the slurry density and oven dry density were shown to be similar due to the foam stability of the foaming agents used in this study in the diluted concentration and mixture condition. 


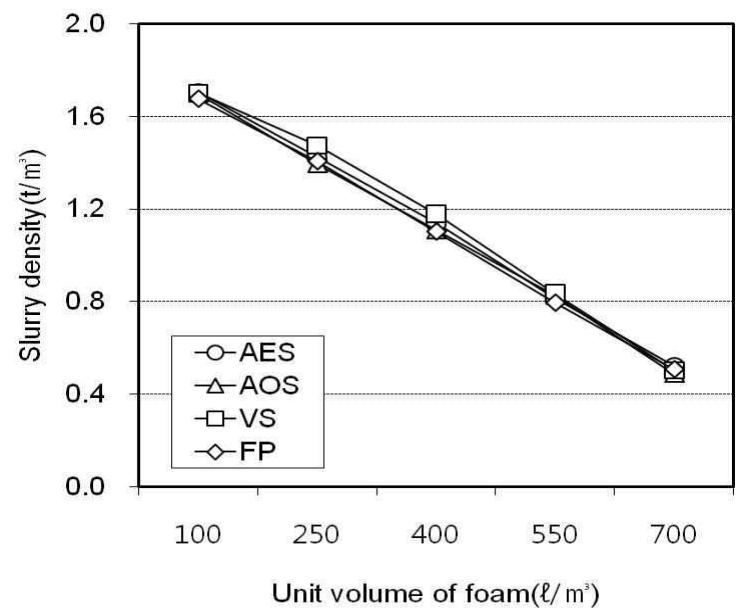

Figure 5. Slurry density according to unit volume of foam and type of foaming agents(AES : Alcohol Ethoxy Sulfate, AOS : Alpha Olefin Sulfonate, VS : Vegetable Soap, FP :

Fe-Protein)

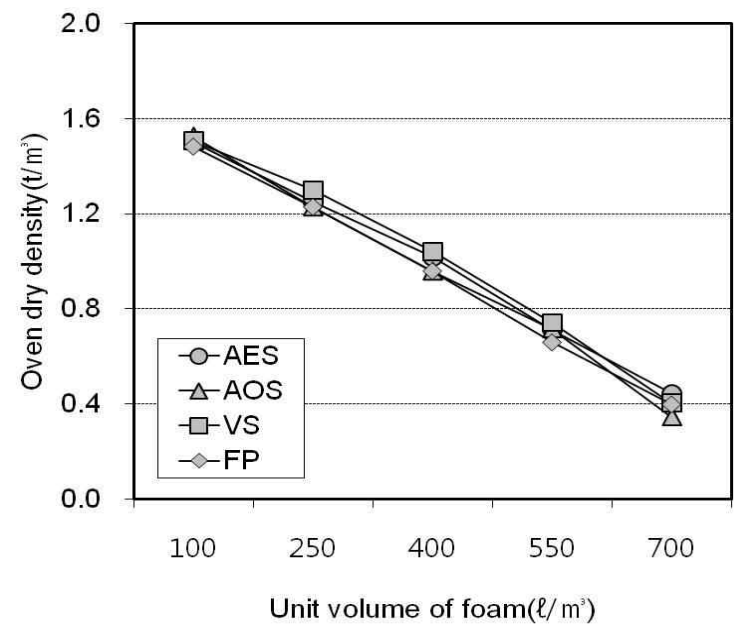

Figure 6. Oven dry density according to unit volume of foam and type of foaming agents(AES : Alcohol Ethoxy Sulfate, AOS

: Alpha Olefin Sulfonate, VS : Vegetable Soap, FP :

Fe-Protein)

It is revealed that the greater the volume of foam, the fewer differences between slurry density and oven density were found. It seems that this phenomenon was observed because of the difference in moisture content after the hydrothermal synthesis because the volume of the matrix comprised of the foamed concrete was decreased.

\subsection{Strength}

Figure 7 illustrates the compressive strength according to type of foam agent and volume of foam. The lower the density, due to increasing amount of foam the lower compressive strength was found to be. At a given volume, FP was usually found to have the highest compressive strength, while AOS had the lowest, notwithstanding some exceptions. AES and VS were shown to be similar. The difference in compressive strength according to type of foaming agent was measured at (4-6) $\mathrm{MPa}$ when the volume of foam was set at (100-400) $\ell / \mathrm{m}^{3}$, and at about $1 \mathrm{MPa}$ when at (550-700) $\ell / \mathrm{m}^{3}$, respectively.

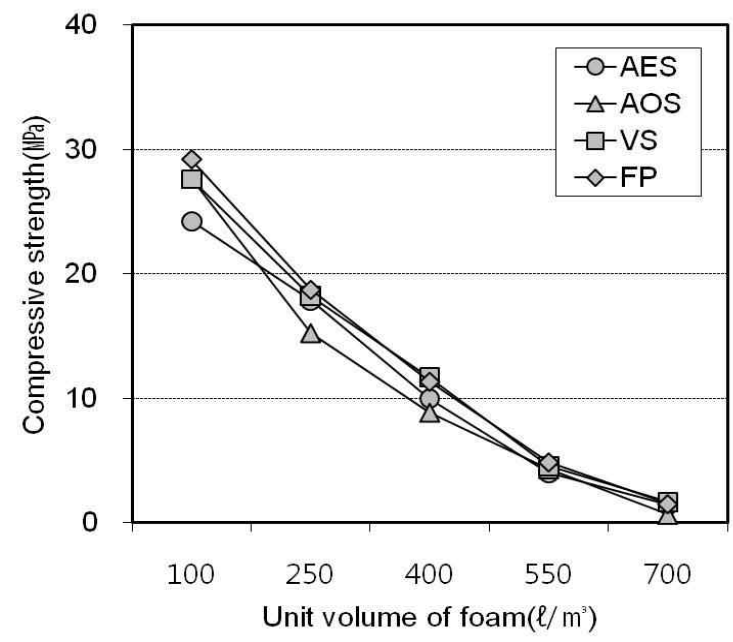

Figure 7. Compressive strength according to unit volume of foam and type of foaming agent (AES : Alcohol Ethoxy Sulfate, AOS : Alpha Olefin Sulfonate, VS : Vegetable Soap, FP : Fe-Protein)

Figure 8 illustrates the flexural strength according to unit volume of foam and type of foaming agents. The flexural strength was shown to be highly similar to compressive strength. The difference in flexural strength was measured at (2-5) $\mathrm{MPa}$ when the volume of foam was set at $(100-250) \ell / \mathrm{m}^{3}$, and about $1 \mathrm{MPa}$ when at $(400-700) \mathrm{l} / \mathrm{m}^{3}$. 


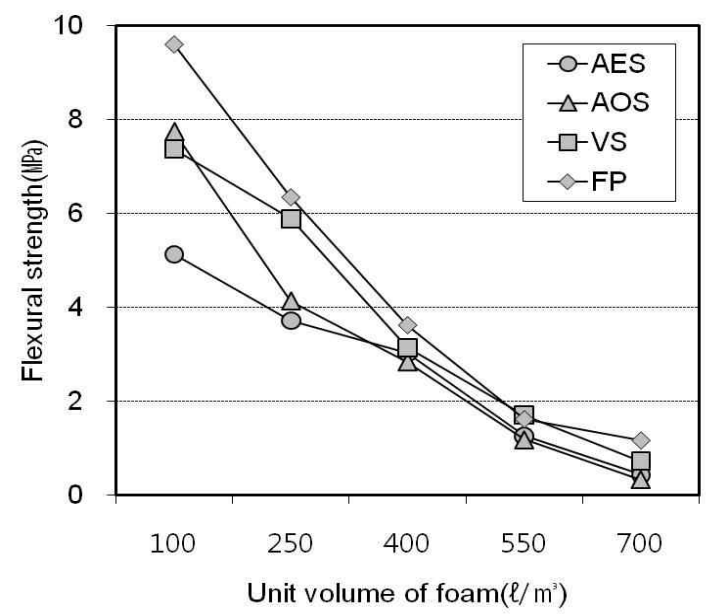

Figure 8. Flexural strength according to unit volume of foam and type of foaming agent (AES : Alcohol Ethoxy Sulfate, AOS : Alpha Olefin Sulfonate, VS : Vegetable Soap, FP : Fe-Protein)

Figures 9 and 10 illustrate the relationship between compressive strength and oven dry density, and the relationship between flexural strength and oven dry density.

$\mathrm{R}^{2}$ of compressive strength and flexible strength were shown to be $98.24 \%$ and $87.56 \%$, respectively. FP was indicated to be the highest under a certain density condition, and the difference in strength between FP and other foaming agents became slightly wider as the density was increased. The property of flexural strength was significant, while the property of compressive strength was insignificant. It is believed that the property of strength was greatly affected by density and porosity under a low-density condition, while it was affected by matrix condition under a high-density condition. Under the high density condition, in the matrix of foamed concrete, the shape and size of foam bubbles were changed by the surface tension and viscosity of the foaming agent dissolved in the liquid[4], which had an impact on the pores of hardened foamed concrete.

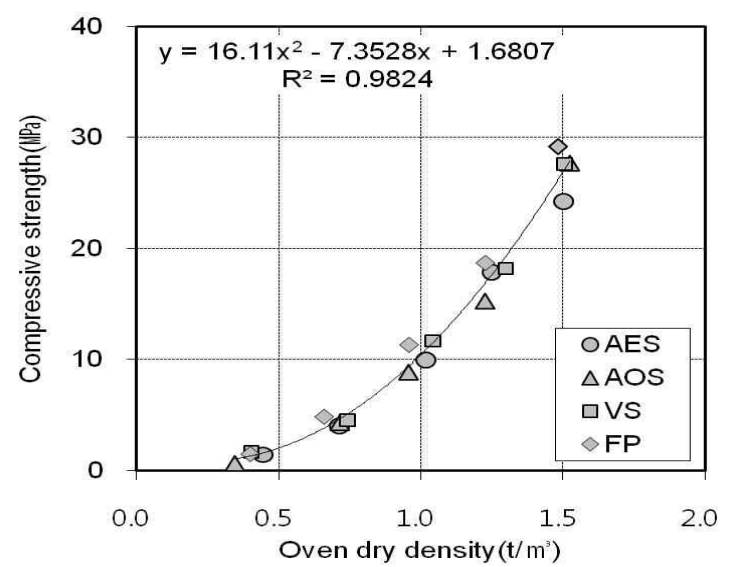

Figure 9. Relationship between compressive strength and oven dry density (AES : Alcohol Ethoxy Sulfate, AOS : Alpha Olefin Sulfonate, VS : Vegetable Soap, FP : Fe-Protein)

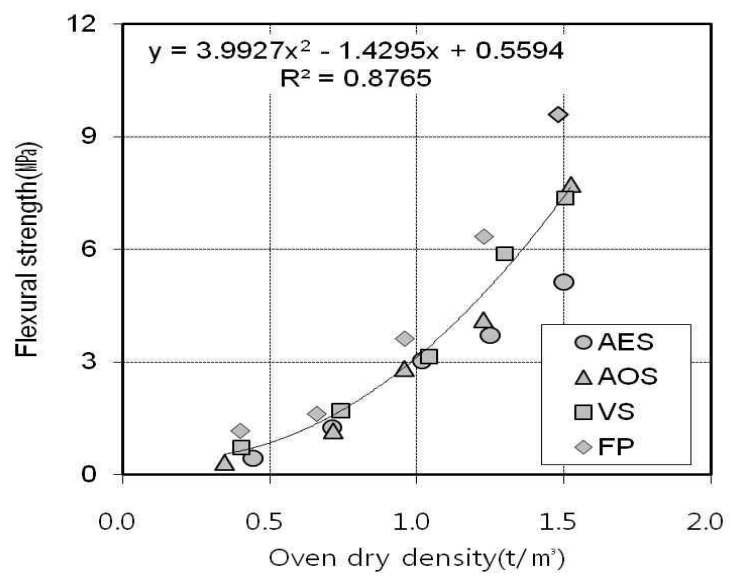

Figure 10. Relationship between flexural strength and oven dry density(AES : Alcohol Ethoxy Sulfate, AOS : Alpha Olefin Sulfonate, VS : Vegetable Soap, FP : Fe-Protein)

\subsection{Thermal conductivity}

Thermal conductivity of concrete is affected by density or porosity[8]. When the unit volume of cement and the thermal conductibility of aggregate go up, the thermal conductivity of concrete also increases $[9,10]$. In order to exclude the impact of matrix comprised of the foamed concrete, a foaming agent and the volume of foam was set to be identical and added at a certain amount. The experiment results are indicated in Figure 11.

Measurements showed that thermal conductivity according to volume of foam increased as the density 
became lower. The thermal conductivity was found to be low in AOS, and high in AES and VS. In addition, the difference in thermal conductivity between foaming agents was similarly measured as (0.03-0.05) $\mathrm{W} / \mathrm{mK}$ when the volume of foam was set at (100-550) $\ell / \mathrm{m}^{3}$, while it was $0.01 \mathrm{~W} / \mathrm{mK}$ when at $700 \mathrm{\ell} / \mathrm{m}^{3}$.

The relationship between density and thermal conductivity changes in a linear manner as shown in Figure 12 , and $\mathrm{R}^{2}$ is $98 \%$. Thermal conductivity is believed to have primarily been affected by the density of foamed concrete or by porosity, as in the precedent studies.

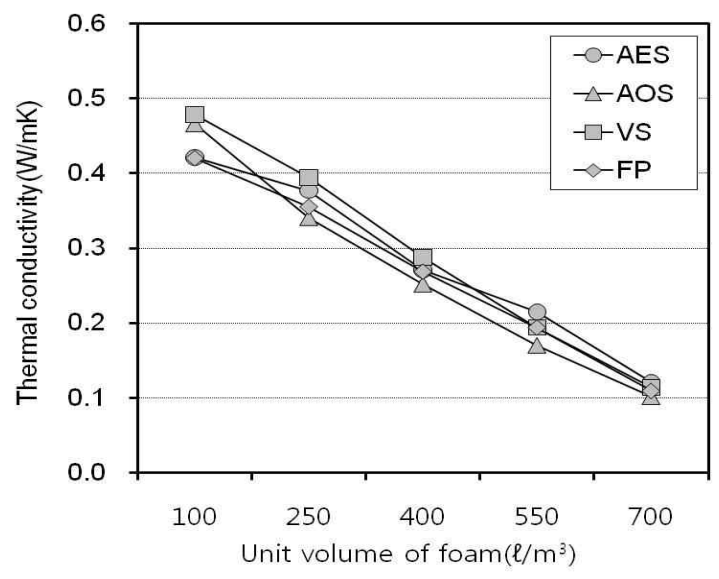

Figure 11. Thermal conductivity according to unit volume of foam and type of foaming agents(AES : Alcohol Ethoxy Sulfate, AOS : Alpha Olefin Sulfonate, VS : Vegetable Soap, FP : Fe-Protein)

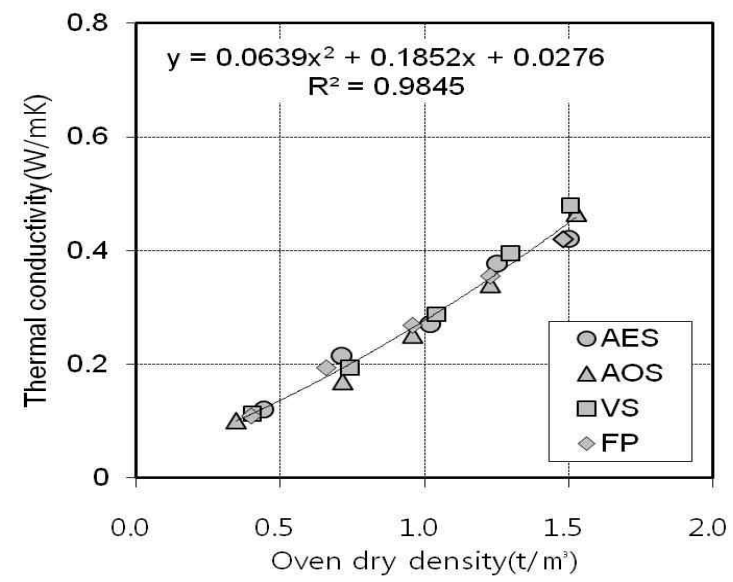

Figure 12. Relationship between thermal conductivity and oven dry density (AES : Alcohol Ethoxy Sulfate, AOS : Alpha Olefin Sulfonate, VS : Vegetable Soap, FP : Fe-Protein)

\section{Conclusion}

1) The unit weight of foam formed by adding a foaming agent becomes lower when the viscosity is higher and the surface tension is lower. For this reason, the unit weight of FP was shown to be highest, while that of VS was lowest. The unit weight of foam can be used as an indicator of the amount of foaming agent used, and thus VS is expected to reduce the amount of foaming agent since it facilitates the formation of foam bubbles.

2) The flow of foamed concrete is increased when the surface tension of the solution in which a foaming agent is dissolved is lower, while it is decreased when the volume of foam is larger. The flow was shown to be highest when using AOS, and lowest when using FP. For this reason, taking workability into account, the foaming agent with a low surface tension is expected to be beneficial.

3) The density was shown to be similar regardless of the foaming agent. There was a difference in density of about $0.3 \mathrm{t} / \mathrm{m}^{3}$ when foam volume was increased by $150 \mathrm{\ell} / \mathrm{m}^{3}$. The lower the difference between slurry density and oven dry density, the higher the volume of foam.

4) The compressive strength and flexural strength according to the type of foaming agent were shown to be highest for FP. In terms of compressive strength, the difference between foaming agents was shown to be about $5 \mathrm{MPa}$, while in terms of flexural strength, the difference was shown to be about $3 \mathrm{MPa}$. The relation between compressive strength and density was shown to be linear, while the flexural strength was shown to be slightly distributed as the density went up.

5) The heat conductivity was similarly measured at (0.03-0.05) W/mK depending on foaming agent when the volume of foam was set at (100-550) $\ell$ / 
$\mathrm{m}^{3}$, while it was $0.01 \mathrm{~W} / \mathrm{mK}$ when at $700 \ell / \mathrm{m}^{3}$. The relationship was indicated to be linear.

6) At a 3\% diluted concentration, fluidity and flexural strength were slightly changed by molecules of foaming agent, surface tension and viscosity depending on foaming agent. The properties of density, compressive strength and heat conductivity were shown to be similar, and thus economic feasibility and workability should be considered when selecting a foaming agent.

\section{Acknowledgement}

This work was supported by the Grant of the Korean Ministry of Education, Science and Technology(The Regional Core Research Program/Zero Energy Green Village Technology Center).

This work was supported by the Human Resources Development of the Korea Insitute of Energy Technology Evaluation and Planning(KETEP) grant funded by the Korea government Ministry of Knowledge Economy(No. 20114010203040)

\section{References}

1. Kim JM, Choi HG, Park SG, An Experimental Study on the Pore Structure and Thermal Properties of Lightweight Foamed Concrete by Foaming Agent Type. Journal of the Korea Institute of Building Construction. 2009 Aug;9(4):6373.

2. Kim JM, Kang C, Engineering Properties of Sound Absorbing Foamed Concrete Using Bottom Ash Depending on Mix Factors. Journal of the Korea Institute of Building Construction, 2009 Oct;9(5):65-72.

3. Holmberg K, Jnsson B, Kronberg B, Lindman B. Surfactants and Polymers in Aqueous Solution. 2nd. ed. Chichester, West Sussex, England:John wiley \& sons; 2003. p. 1-2.

4. David R. Karsa. Surfactants in Polymers, Coatings, Inks and Adhesives. V.1. Blackwell Publishing. UK.; 2003. p. 95-9.

5. Kim JM, Kwak EG, Oh KC., Kang C. Properties of Bubble According to Types and Concentrations of Concrete Foaming Agent. Journal of the Korea Concrete Institute. 2011 Apr
;23(2):151-8

6. Kasai Y. [New Admixtures for Cement \& Concrete.] Tokyo: Technique-Lecture Hall; 2007. p. 272-80. Japanese.

7. David R. Karsa. Surfactants in Polymers, Coatings, Inks and Adhesives. V.1. Oxford, England: Blackwell Publishing; 2003.p. 95-9.

8. Short, A, Kinniburg W. lightweight Concrete. 3rd ed. London: Applied Science; 1978. p. 113.

9. Gl R, Uysal H, Demirboğa R. Investigation of the Thermal Conductivity of Lightweight Concrete Made with Kocap i nr's Pumice Aggregate. Advanced in Civil Eng. 1997;2:553-62.

10. Ashworth T, Ashworth E, Graves RS, Wysocki DC. Insulation Materials: Testing and Applications. ASTM STP. Philadelphia (PA);1991. p. 415-29. 